\title{
Research cruise data on the biology of the lesser flying squid, Todaropsis eblanae, in the North Sea
}

\author{
Karsten Zumholz a and Uwe Piatkowski \\ Leibniz-Institut für Meereswissenschaften, IFM-GEOMAR, Düsternbrooker Weg 20, 24105 Kiel, Germany
}

Accepted 30 June 2005

\begin{abstract}
A total of 324 specimens of the ommastrephid squid Todaropsis eblanae, collected from bottom trawl surveys in the North Sea was examined. Information on seasonal length frequency distributions and relationships of beak size to mantle length and wet body mass from the northernmost distribution of the species is supplied. The overall male: female ratio was 1: 0.78. Maturing males and females were found in winter and summer, while fully mature animals were observed only in summer. Sexual maturity in females occurred in bigger sizes than in males. Specimens were caught in water depths between 56 and $170 \mathrm{~m}$ throughout the whole investigated area except from the German Bight. This paper presents the first biological data on T. eblanae in the North Sea derived from scientific surveys.
\end{abstract}

Key words: Todaropsis eblanae / Cephalopoda / Ommastrephidae / North Sea / reproductive biology / beak / lower rostral length

\begin{abstract}
Résumé - Données de campagnes océanographiques sur la biologie du calmar Todaropsis eblanae en mer du Nord. Pour cette étude, 324 calmars Ommastraephidés de l'espèce Todaropsis eblanae récoltés durant des campagnes scientifiques de chalutage de fond en mer du Nord ont été analysés. Les fréquences de taille, relations entre la taille du bec et celle du manteau et les poids frais, décrits ici concernent la partie la plus nordique de l'aire de répartition de cette espèce. Globalement, le sex ratio est de 78 femelles pour 100 mâles. Des mâles et des femelles en cours de maturation sexuelle ont été trouvés en été comme en hiver alors que les animaux à maturité complète n'ont été observés qu'en été. La maturité sexuelle est atteinte à une taille plus grande chez les femelles que chez les mâles. Les captures de ce calmar ont eu lieu par des profondeurs de 56 à $170 \mathrm{~m}$ et dans toute la zone prospectée par les campagnes à l'exception du German Bight. Cet article présente les premières données biologiques concernant T. eblanae en mer du Nord obtenues à partir de campagnes scientifiques.
\end{abstract}

\section{Introduction}

The lesser flying squid, Todaropsis eblanae (Ball 1841), which is widely distributed in the eastern Atlantic from $60^{\circ} \mathrm{N}$ to $36^{\circ} \mathrm{S}$ and in the Mediterranean Sea (Roper et al. 1984), is a relatively small ommastrephid species with a maximum recorded mantle length of $22 \mathrm{~cm}$ for males and $29 \mathrm{~cm}$ for females. It constitutes an important by-catch species in some demersal fisheries of southern European countries but is only a minor component of the catch in northern Europe, where it is still discarded (Robin et al. 2002). Few studies of T. eblanae have been undertaken in North Sea waters and published information is based on data from commercial catches only. Robin et al. (2002) gave a detailed analysis of the commercial bycatch of T. eblanae in the Bay of Biscay and the southern Celtic Sea. Hastie et al. (1994) investigated the bycatch of Scottish commercial fishing boats in Shetland Waters and off Aberdeen. For the rest of the North Sea, published information does not exist and little is known about the biology and life history of T. eblanae in this area. Todaropsis eblanae has been described

\footnotetext{
a Corresponding author: kzumholz@i fm-geomar.de
}

as rare in Scottish waters, but it occasionally appears in very large numbers in certain areas (Rae and Lamont 1963; Hastie et al. 1994) and it was found regularly in the bottom trawls presented in the current study.

The samples collected for this investigation provide biological information on T. eblanae caught during ten ICES International Bottom Trawl Surveys in the North Sea. They give new insight into the population structure and spatial distribution in this area. Furthermore, our study provides new relationships of beak size to mantle length and wet body mass for a wide size range of T. eblanae in the North Sea. These data are essential to estimate squid biomass ingestions of marine mammals, seabirds and fish from this region.

\section{Materials and methods}

324 specimens of T. eblanae were collected on board of FRV "Walther Herwig III" in the North Sea between $53^{\circ} \mathrm{N}$ and $62^{\circ} \mathrm{N}$ (sampling sites, Fig. 1). Specimens were sampled during ten cruises in the course of the ICES International Bottom Trawl Survey (IBTS) in each winter (January/February) and summer (July/August) from 1998 to 2002. A total of 
Table 1. Numbers of Todaropsis eblanae sampled in the North Sea by FRV "Walther Herwig III" during 1998-2003. Line one gives quarter and year.

\begin{tabular}{lcccccccccc}
\hline & 1 & 3 & 1 & 3 & 1 & 3 & 1 & 3 & 1 & 3 \\
& 1998 & 1998 & 1999 & 1999 & 2000 & 2000 & 2001 & 2001 & 2002 & 2002 \\
\hline Cruise \# & $\mathrm{WH}$ & $\mathrm{WH}$ & $\mathrm{WH}$ & $\mathrm{WH}$ & $\mathrm{WH}$ & $\mathrm{WH}$ & $\mathrm{WH}$ & $\mathrm{WH}$ & $\mathrm{WH}$ & $\mathrm{WH}$ \\
& 192 & 197 & 202 & 208 & 214 & 219 & 225 & 230 & 236 & 241 \\
\hline $\mathrm{N}^{\circ}$ of T. eblanae & 32 & 77 & 81 & 50 & 24 & 2 & 8 & 21 & 0 & 29 \\
$\mathrm{~N}^{\circ}$ of hauls & 66 & 107 & 70 & 168 & 101 & 74 & 70 & 74 & 78 & 152 \\
$\mathrm{~N}^{\circ}$ of T. eblanae per hour trawl time & 1.0 & 1.4 & 2.3 & 0.6 & 0.5 & 0.1 & 0.2 & 0.6 & 0 & 0.4 \\
\hline
\end{tabular}

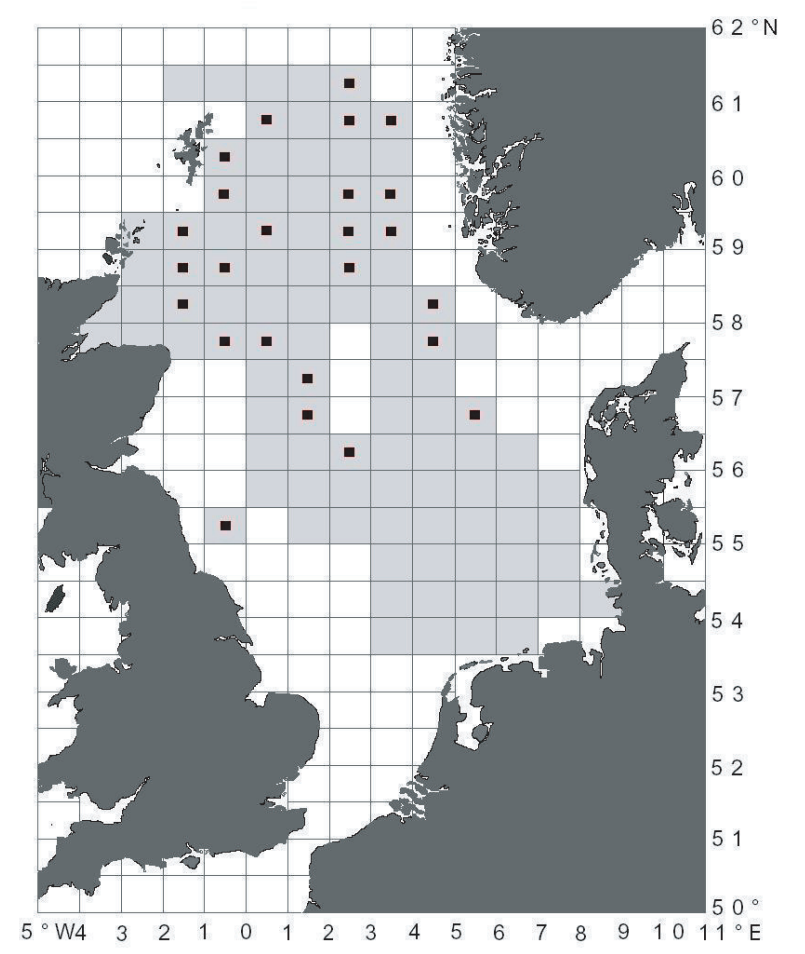

Fig. 1. Map of the survey area. ICES-rectangles, where hauls were performed, are given in light grey. Hauls where T. eblanae was caught are given as black dots.

960 trawls was carried out using a GOV-trawl (mesh-opening of $20 \mathrm{~mm}$ in the codend) at depth from 20 to $180 \mathrm{~m}$ during daylight hours between 7:00 h and 19:00 h GMT (for detailed information see: IBTS Report, ICES 2000). Squid were frozen immediately after capture. Measurements and further analysis were performed in the laboratory at IFM-GEOMAR, Kiel. The animals were sexed and maturity stages (I, immature; II-III, maturing; IV-V, mature) were estimated according to the appearance and relative size of the reproductive organs (Lipinski 1979). Dorsal mantle length (DML) was measured to the nearest $1 \mathrm{~mm}$, total body wet mass (BM) was measured to the nearest $1 \mathrm{~g}$. Rostral length of the lower beak (LRL) was recorded to the nearest $0.1 \mathrm{~mm}$ using digital callipers.

\section{Results}

Table 1 summarizes the numbers of Todaropsis eblanae caught during 1998 to 2002 and the CPUE expressed as mean number of T. eblanae per hour trawl time.

\subsection{Distribution}

Todaropsis eblanae was present throughout the whole investigated area except from the German Bight in the southeastern survey region (Fig. 1). The northernmost occurrence was recorded at $61^{\circ} 15.33^{\prime} \mathrm{N}$. Specimens were caught in water depths between 56 and $170 \mathrm{~m}$. Number, location and depths of sampling stations differed considerably between summer and winter and between the years, so that statistical analyses of seasonal or annual differences in geographical distribution patterns did not seem to be meaningful.

\subsection{Population structure}

The length-frequency distribution of Todaropsis eblanae differed considerably between summer and winter (mediantest, $p<0.0001$ ) (Figs. 2a,b). During winter there were no differences in mantle length between males and females (mediantest, $p>0.9)$ while in summer females were notably bigger than males (median-test, $p<0.001$ ).

In winter, the proportion of mature animals was significantly lower than in summer $\left(\chi^{2}\right.$-test, $\left.p<0.0001\right)$. In winter most squid were maturing (II and III) (Fig. 3). Few mature males and no mature females were observed. In summer mature squid (stages IV and V) predominated in the population. No juveniles (stage I) were observed. In winter the proportion of mature animals was significantly higher in males than in females $\left(\chi^{2}\right.$-test, $\left.p<0.01\right)$ while in summer no differences were visible $\left(\chi^{2}\right.$-test, $\left.p>0.31\right)$

Sexual maturity occurred:

in males (stages IV and V) 85-160 mm mantle length (mean size at maturity $=123 \mathrm{~mm}, \mathrm{SD}=13 \mathrm{~mm}, N=69$ ) whereas in females, it was evident in bigger sizes 120-190 mm (mean = $164 \mathrm{~mm}, \mathrm{SD}=15 \mathrm{~mm}, N=52$ ).

The overall male: female ratio was 1: 0.78. Males were more numerous than females during both winter and summer. The respective length-weight relationships observed were similar for both sexes. Using the length-weight model $\mathrm{W}=$ $a \mathrm{~L}^{b}$, where $\mathrm{W}=$ wet body mass $(\mathrm{g})$ and $\mathrm{L}=$ dorsal mantle length $(\mathrm{mm})$, it was:

$$
\begin{aligned}
& \mathrm{W}=0.00013105 \mathrm{~L}^{2.8541}\left(r^{2}=0.972 ; N=178\right) \quad \text { in males; } \\
& \mathrm{W}=0.0003124 \mathrm{~L}^{2.6597}\left(r^{2}=0.968 ; N=139\right) \quad \text { in females }
\end{aligned}
$$

\subsection{Beak analyses}

We found no differences between the beak morphology of males and females; therefore equations were calculated for 

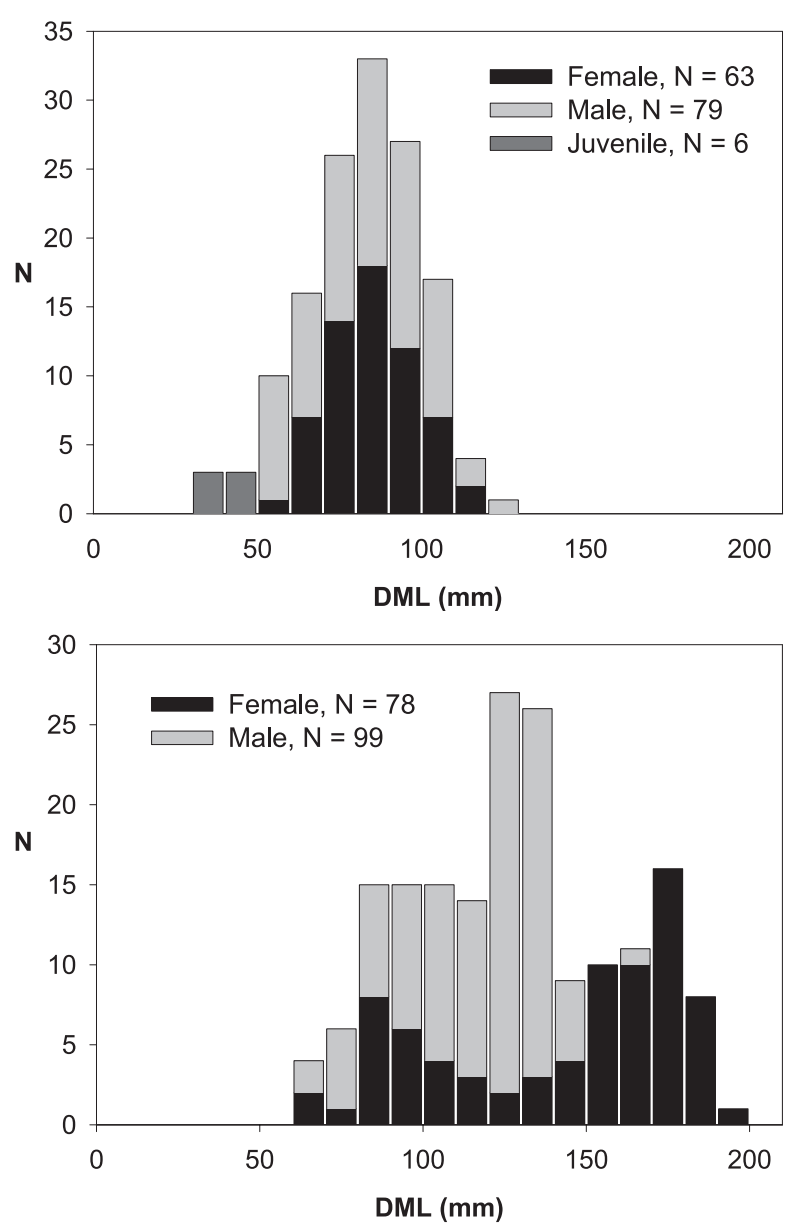

Fig. 2. Todaropsis eblanae. Length frequency of T. eblanae captured by bottom trawl in the North Sea in winter (a) and summer (b). Black: females, light grey: males, dark grey: juveniles. $N=$ total number of specimens.

both sexes combined (Fig. 4). The observed equations for lower rostral length (LRL in $\mathrm{mm}$ ) against both dorsal mantle length (DML in $\mathrm{mm}$ ) and wet body mass (BM in $\mathrm{g}$ ) in the investigated size range $(\mathrm{ML}=40-190 \mathrm{~mm} ; \mathrm{LRL}=1.7-6.0 \mathrm{~mm})$ were:

$$
\begin{aligned}
\mathrm{DML} & =32.528 \mathrm{LRL}-4.54, & r^{2}=0.892, & N=313 \\
\mathrm{BM} & =2.9042 \mathrm{LRL}^{2.724}, & r^{2}=0.912, & N=313 .
\end{aligned}
$$

\section{Discussion}

Todaropsis eblanae appears to be present throughout the entire North Sea except from the southeastern parts. The absence of T. eblanae in the German Bight is probably due to low water depth (shallower than $50 \mathrm{~m}$ ). The northernmost record in our study was $61^{\circ} 15.33^{\prime} \mathrm{N}$, probably representing the northernmost caught specimen recorded in the literature. The catches of $T$. eblanae per hour trawl time during 1998 to 2002 ranged between 0 and 2.3 (Table 1). The highest CPUE was observed in 1998 and 1999. However, there was no evidence of exceptional high abundance in certain areas

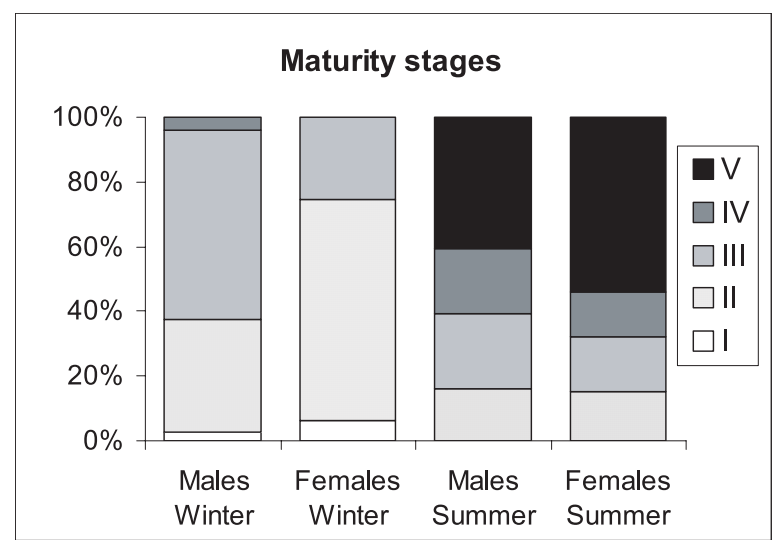

Fig. 3. Todaropsis eblanae. Chart showing seasonal relative proportions of maturity stages observed for male/female T. eblanae. Stage I: juvenile; stages II and III: maturing; stages IV and V: mature.

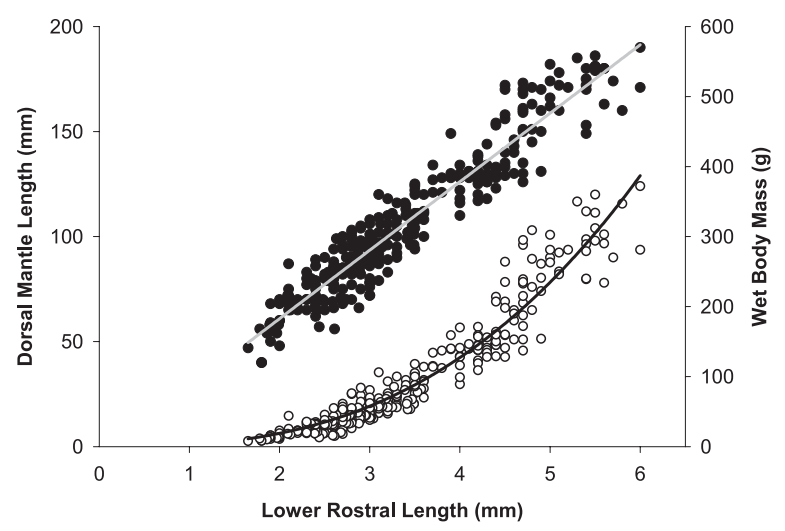

Fig. 4. Todaropsis eblanae. Lower beak rostral length LRL of $T$. eblanae versus dorsal mantle length DML (black dots) and wet body mass BM (open circles). Black lines represent regression lines. $N=313$.

or certain years as described by Rae and Lamont (1963) and Hastie et al. (1994). As these sudden increases in local abundance are reported to appear irregularly, apparently there has been no such an event between 1998 and 2002 in the North Sea. The observation that males were slightly more numerous than females differs from the results of Hastie et al. (1994), who found a male: female ratio of 1: 1.2 in Scottish waters. However, these samples were taken from a commercial fishing boat, probably catching bigger females more efficiently. Hernandez-Garcia (2002) found no distinct domination of males or females in Northwest African waters, while for Spanish waters a male: female ratio of 1: 0.85 is reported (González et al. 1994). Similar length-weight curves of T. eblanae have been estimated by Cooper (1979) for South African waters, González et al. (1994) for Spanish waters and Hastie et al. (1994) for Scottish waters, indicating similar growth patterns throughout the whole distribution range.

From studies of T. eblanae in the Mediterranean, MangoldWirz (1963) observed that males and females matured at mantle lengths of around 110-140 mm and 160-190 mm, respectively. In Spanish Atlantic waters, the size of mature males ranged from 104 to $169 \mathrm{~mm}$, while the size of mature females ranged from 140 to $219 \mathrm{~mm}$ (González et al. 1994). 
Our findings suggest that T. eblanae in the North Sea reaches maturity at smaller sizes, perhaps due to lower water temperatures and smaller adult size. From studies of T. eblanae in Scottish waters, Hastie et al. (1994) found that males and females matured at mantle lengths of around $92-140 \mathrm{~mm}$ and 110-205 mm respectively, which fits to our findings.

Because there were only two sampling periods per year, our data cannot provide distinct seasonal maturity patterns. However, maturity data presented in this study are in agreement with the results of Hastie et al. (1994), who suggest a spawning-season from June to November in Scottish waters. Mangold-Wirz (1963), Arkhipkin and Laptikhovsky (2000) and Robin et al. (2002) describe a spawning period from March to September in the Mediterranean, the north-west African shelf and the northern Bay of Biscay, respectively. Collins et al. (2002) found early life T. eblanae (DML $=7$ to $22 \mathrm{~mm}, n=4$ ) during a zooplankton survey in January 1988 which might suggest that hatching takes place during early winter.

Length frequency data for winter samples suggest the existence of one cohort in the North Sea. Data for summer show two peaks in female length frequency. However, any kind of traditional length-frequency analysis for assessment of squid age and growth should be viewed with scepticism due to the intriguing growth pattern of squid, related to fast growth and short life-cycle (Pauly 1985; Pierce et al. 1994). A life cycle of approximately one year has been described for the Northwest African shelf population (Arkhipkin and Laptikhovsky 2000) and for the northern Bay of Biscay (Robin et al. 2002). These studies, however, are based on statolith ageing, which is required to confirm this prediction for the North Sea population as well. In comparison to the results from Hastie et al. (1994) the observed length-frequencies and, as a consequence of this, the maturity patterns differ due to different sampling gears used in the studies. Nevertheless, we found similar trends, which confirm our suggestions about the life-cycle of T. eblanae in the North Sea.

Beak analyses showed that Todaropsis eblanae is a suitable candidate for estimating biomass from beak lengths from predator stomachs, as the regressions between beak length and both mantle length and body mass show high $r$ values. As Jackson (1995) demonstrated, this is not the case for all squid species. However, since beaks of T. eblanae are difficult to distinguish from Illex coindetii beaks (Clarke 1986) the utility is actually limited in this case.

The bottom trawl used for this survey may have been selective in its sampling. Although T. eblanae is certainly more demersal than other members of the family Ommastrephidae, which are typically oceanic and pelagic, the bottom trawl catch is unlikely to provide perfectly adequate samples of the population. Small and large specimens are probably underestimated due to the large mesh size and slow tow speed, respectively. However, these catch data have the main advantage of standardized trawl conditions. Up to now, published information on T. eblanae in the North Atlantic is entirely based on commercial landings, which are most likely to be biased in several ways. The ICES-Bottom Trawl Surveys in the North Sea will continue during the next years. Therefore we expect an extension of this long time data series, resulting in an improved knowledge of the biology of T. eblanae in the North Sea.

Acknowledgements. We are grateful to the crew and the scientific staff of FRV "Walther Herwig III" for their help during on board sampling. Special thanks go to S. Ehrich and I. Wilhelms (Institute for Sea Fisheries, Hamburg). Constructive comments of D. Schnack and G.J. Pierce helped to improve the manuscript.

\section{References}

Arkhipkin A.I., Laptikhovsky V.V., 2000, Age and growth of the squid Todaropsis eblanae (Cephalopoda: Ommastrephidae) on the north-west African shelf. J. Mar. Biol. Assoc. UK 80, 747-748.

Clarke M.R., 1986, A handbook for the identification of cephalopod beaks. Oxford University Press, New York.

Collins M.A., Yau C., Boyle P.R., Friese D., Piatkowski U., 2002, Distribution of cephalopods from plankton surveys around the British Isles. Bull. Mar. Sci. 71, 239-254.

Cooper J., 1979, Length-mass relationships, water content and energy values for two species of squid, Loligo reynaudi and Todaropsis eblanae off the south-western cape. Fish. Bull. S. Afr. 11, 43-45.

Gonzalez A.F., Rasero M., Guerra A., 1994, Preliminary study of Illex coindetii and Todaropsis eblanae (Cephalopoda: Ommastrephidae) in northern Spanish Atlantic waters. Fish. Res. 21, 115-126.

Hastie L.C., Joy J.B., Pierce G.J., Yau C., 1994, Reproductive biology of Todaropsis eblanae (Cephalopoda: Ommastrephidae) in Scottish waters. J. Mar. Biol. Assoc. UK 74, 367-382.

Hernandez-Garcia H., 2002, Reproductive biology of Illex coindetii and Todaropsis eblanae (Cephalopoda: Ommastrephidae) off northwest Africa. Bull. Mar. Sci. 71, 347-366.

ICES, 2000, Report of the International Bottom Trawl Survey in the North Sea, Skagerrak and Kattegat in 1999: Quarter 1. Addendum I to ICES CM 2000/D:7.

Jackson G. D., 1995, The use of beaks as tools for biomass estimation in the deepwater squid Moroteuthis ingens (Cephalopoda: Onychoteuthidae) in New Zealand waters. Polar Biol. 15, 9-14.

Lipinski M.R., 1979, Universal maturity scale for commercially important squids (Cephalopoda: Teuthoidea). ICNAF Res. Doc. 79/II/38, 53-64.

Mangold-Wirz K., 1963, Biologie des céphalopodes benthiques de la mer Catalane. Vie Milieu Suppl. 13, 1-285.

Pauly, D., 1985, Population dynamics of short-lived species, with emphasis on squids. NAFO Sci. Counc. Stud. 9, 143-154.

Pierce G.J., Boyle P.R., Hastie L.C., Key L., 1994, The life history of Loligo forbesi (Cephalopoda: Loliginidae) in Scottish waters. Fish. Res. 21, 17-41.

Rae B.B., Lamont J.M., 1963, Rare marine invertebrates found in the Scottish area. Scottish Naturalist 71, 23-28.

Robin J.P., Denis V., Royer J., Challier L., 2002, Recruitment, growth and reproduction in Todaropsis eblanae (Ball 1841) in the area fished by French Atlantic trawlers. Bull. Mar. Sci. 71, 711-724.

Roper C.F.E., Sweeney M.J., Nauen C.E., 1984, Cephalopods of the world, FAO Species catalogue. FAO Fish. Synop. 125, Vol. 3. 